\title{
Emerging role of GLP-I receptor agonists in the treatment of obesity
}

This article was published in the following Dove Press journal:

Diabetes, Metabolic Syndrome and Obesity:Targets and Therapy 16 July 2010

Number of times this article has been viewed

\author{
Lisa M Neff' \\ Robert F Kushner ${ }^{2}$ \\ 'Division of Endocrinology, \\ Metabolism, and Molecular \\ Medicine, ${ }^{2}$ Division of General \\ Medicine, Department of Medicine, \\ Northwestern University Feinberg \\ School of Medicine, Chicago, \\ IL, USA
}

Correspondence: Lisa M Neff

645 N Michigan Ave, Suite 530-30,

Chicago, IL 606 I I, USA

$\mathrm{Tel}+\mathrm{I} 3$ I 25033267

Fax + I 3129268693

Email I-neff@northwestern.edu

\begin{abstract}
The prevalence of obesity has increased dramatically in recent decades, both in the US and worldwide. Pharmacotherapy can augment the weight-reducing effects of lifestyle modification and can facilitate long-term weight maintenance. However, there is a paucity of pharmacologic agents approved for the treatment of obesity, and the use of existing weight loss medications is frequently limited by contraindications, drug interactions, adverse effects, limited coverage by third-party payers, and cost. In recent years, there has been an increased understanding and appreciation of the role of gastrointestinal hormones in the control of body weight. One such hormone, GLP-1, also plays an important role in glucose homeostasis. GLP-1 receptor agonists, such as exenatide and liraglutide, have been developed and are already approved for the treatment of type 2 diabetes. There has also been interest in the use of GLP-1 receptor agonists for the treatment of obesity in nondiabetic patients. This review explores the potential utility and limitations of exenatide and liraglutide as therapeutic agents for obesity.
\end{abstract}

Keywords: obesity, GLP-1, exenatide, liraglutide

\section{Introduction}

In the US, the prevalence of obesity has increased dramatically in recent decades. Data from the National Health and Nutrition Examination Survey suggest that, in 2007-2008, 34\% of American adults had a body mass index (BMI) in the obese range ( $\geq 30 \mathrm{~kg} / \mathrm{m}^{2}$ ), up from just $14 \%$ in $1971-1974 .{ }^{1,2}$ Obesity is a chronic metabolic disorder that affects all organ systems. Excess adiposity increases the risk of a variety of comorbid conditions, including type 2 diabetes, hypertension, dyslipidemia, cardiovascular disease, obstructive sleep apnea, nonalcoholic fatty liver disease, osteoarthritis, and some types of cancer. Fortunately, even modest weight loss (eg, 5\%-10\% of initial body weight) can reduce the severity of existing comorbidities and prevent the development of new ones. ${ }^{3-5}$ However, weight loss also activates a complex system of neuroendocrine signals that increase appetite and reduce energy expenditure, making additional weight loss and maintenance of a lower body weight very challenging.

\section{Pharmacotherapy for obesity}

Pharmacotherapy can enhance the weight-reducing effects of lifestyle changes and can facilitate long-term weight maintenance. ${ }^{6,7}$ As a result, weight loss medication can serve as a useful adjunct to lifestyle modification in the treatment of obesity. However, it is important to note that obesity is a chronic condition, and weight regain often occurs if treatment is stopped. Therefore, in patients who choose pharmacotherapy as a tool to aid in weight management, long-term employment of medication 
is usually required. Unfortunately, only two medications, sibutramine and orlistat, are approved by the US Food and Drug Administration (FDA) for long-term use. Several older weight loss medications, including the appetite suppressant phentermine, are approved for short-term use (typically $<12$ weeks), but they are frequently used off-label for longer periods. Unfortunately, little is known about the long-term safety of these older medications.

Sibutramine (Meridia ${ }^{\circledR}$ ) is a centrally-acting norepinephrine, serotonin, and dopamine reuptake inhibitor that works primarily as an appetite suppressant. Orlistat $\left(\mathrm{Xenical}^{\circledR}\right)$, on the other hand, is a lipase inhibitor that acts in the gastrointestinal tract to prevent the absorption of about $30 \%$ of ingested fat. Dozens of randomized controlled trials confirm that sibutramine and orlistat are safe and modestly effective for long-term obesity management. ${ }^{8,9}$ Meta-analyses suggest that the average placebo-subtracted weight loss is $4.6 \%$ with sibutramine and $2.9 \%$ with orlistat. ${ }^{10} \mathrm{Clinical}$ trials have also demonstrated improvements in triglycerides, high-density lipoprotein (HDL)-cholesterol, fasting plasma glucose, and hemoglobin $\mathrm{A}_{1 \mathrm{c}}\left(\mathrm{HbA}_{1 \mathrm{c}}\right)$ with sibutramine and improvements in low-density lipoprotein (LDL)-cholesterol, blood pressure, fasting plasma glucose, and $\mathrm{HbA}_{1 \mathrm{c}}$ with orlistat. ${ }^{8-11}$

Each of the currently available weight loss agents can be very useful in certain groups of patients, but their clinical utility is often limited by side effects, contraindications, or drug interactions. Sibutramine, for example, can produce small increases in blood pressure and pulse, ${ }^{12}$ and its use is contraindicated in patients with uncontrolled hypertension, coronary heart disease, arrhythmias, or a history of stroke. In addition, concomitant use of sibutramine and other serotonergic agents (including many antidepressants) may raise the risk of the rare but potentially fatal serotonin syndrome. Orlistat is minimally absorbed, and systemic side effects are so rare that a lower-dose formulation is now available over-the-counter. However, gastrointestinal symptoms, such as oily stools and fecal urgency, are quite common and can adversely affect patient adherence. ${ }^{10}$ Furthermore, orlistat can interfere with the absorption of cyclosporine and amiodarone, and can enhance the effects of warfarin by reducing the absorption of vitamin $\mathrm{K}$. Phentermine, which has sympathomimetic actions, has a side effect profile that is very similar to that of sibutramine, and it too is contraindicated for use in patients with uncontrolled hypertension or cardiovascular disease.

Another barrier to the use of currently available weight loss medications is that their costs are often not covered by health insurance plans. Sibutramine and prescription-strength orlistat typically cost over $\$ 100$ a month, which puts them out of reach for many patients who might benefit from their use. The older weight loss agents, such as phentermine, are typically more affordable because generic formulations are available.

As a result of adverse effects, contraindications, drug interactions, and costs, many patients who might benefit from pharmacotherapy for obesity do not receive this treatment. Additional treatment options are clearly needed. A relatively new class of agents, the glucagon-like peptide 1 (GLP-1) receptor agonist family, has garnered intense interest as a potential therapeutic agent for obesity management.

\section{GLP-I receptor agonist class}

In recent years, there has been an increased understanding and appreciation of the role of gastrointestinal hormones in the control of glucose metabolism and body weight. One such hormone, GLP-1, is produced primarily by enteroendocrine L-cells located in the ileum, although these cells are also present throughout the small intestine and colon. ${ }^{13,14}$ GLP-1 is secreted in response to food intake and the presence of nutrients in the intestinal lumen. ${ }^{15}$ GLP-1, along with other gut peptides, is responsible for the phenomenon known as the incretin effect, in which the insulinemic response to an oral glucose load exceeds that elicited by an equivalent amount of glucose delivered intravenously. GLP-1 also plays a role in the ileal brake mechanism, in which the presence of nutrients in the ileal lumen leads to a decrease in gastric motility.

The GLP-1 receptor belongs to the G-protein coupled family of receptors, and it is known to be present in the pancreas, gastrointestinal tract, brain, and other tissues, including the heart. ${ }^{16}$ GLP-1 receptors have also been identified in vagal afferent neurons in the rat nodose ganglion, and studies suggest that GLP-1 may act on target organs not only through classic hormonal mechanisms but also through neural pathways. ${ }^{17,18}$ In the pancreas, important actions of GLP-1 include the enhancement of glucose-dependent insulin synthesis and secretion, and stimulation of beta-cell proliferation. ${ }^{19}$ GLP-1 also inhibits inappropriate alpha-cell glucagon secretion, which occurs despite hyperglycemia in patients with type 2 diabetes. ${ }^{20}$ This reduction of glucagon secretion lessens hepatic glucose output and contributes to the antidiabetic effects of GLP-1. Important gastrointestinal effects of GLP-1 include reductions in gastric acid secretion and gastrointestinal motility, both of which are mediated primarily through the vagus nerve. ${ }^{18}$ In the brain, GLP-1 receptors are found in the paraventricular nucleus and other hypothalamic regions involved in the regulation of appetite 
and body weight. ${ }^{21}$ GLP-1 appears to cross the blood-brain barrier, ${ }^{22,23}$ and postprandial increases in circulating GLP-1 are temporally associated with neural activation in areas of the hypothalamus and prefrontal cortex that are involved in the regulation of feeding behavior. ${ }^{24}$ However, in rats, the GLP-1-induced increase in hypothalamic neural activity is attenuated by vagotomy, suggesting that the vagus nerve plays a role in the central nervous system response to peripheral GLP-1. ${ }^{25}$

GLP-1 clearly plays a role in regulating satiety, feeding behavior, and body weight. In rodents, intracerebroventricular administration of GLP-1 reduces food intake. ${ }^{26,27}$ In humans, peripheral administration of GLP-1 has been shown to increase satiety and reduce energy intake. ${ }^{28,29}$ Studies suggest that chronic administration of GLP-1 can reduce body weight in both rats ${ }^{30}$ and humans. ${ }^{31}$ However, GLP-1 receptor knockout mice exhibit normal feeding behaviors and body weights, suggesting that GLP-1 plays a supporting rather than a primary role amidst the complex and overlapping neurohormonal pathways regulating body weight. $^{32}$

In addition to its effects on appetite and food intake, GLP-1 may also play a role in energy metabolism. Studies in rodents suggest that administration of GLP-1 may increase energy expenditure and alter fuel utilization, favoring the oxidation of fat over carbohydrate..$^{27,33}$ These findings are supported by a small $(n=46)$ cross-sectional study in humans, which suggested that higher fasting GLP-1 levels are associated with higher rates of resting energy expenditure and fat oxidation. ${ }^{34}$ Exogenous administration of GLP-1 was shown to increase resting energy expenditure in a small clinical trial involving 13 healthy adults. ${ }^{35}$ However, it has also been suggested that GLP-1 administration reduces diet-induced thermogenesis (ie, the energy expended as a direct result of food consumption, digestion, and absorption), potentially because of its effects on gastrointestinal motility. ${ }^{36,37}$

As compared with lean controls, obese individuals have been shown to have an attenuated secretion of GLP-1 in response to either an oral carbohydrate $\operatorname{load}^{38}$ or a mixed meal. ${ }^{39}$ Furthermore, Verdich et al demonstrated that dietinduced weight loss increases postprandial GLP-1 secretion in obese volunteers. ${ }^{39}$ These findings, as well as the observed effects of GLP-1 administration on appetite, food intake, and body weight, as discussed above, stimulated interest in the use of GLP-1 in the treatment of obesity. Data about the antidiabetic effects of GLP-1 (ie, enhancement of betacell responsiveness to elevated glucose levels, promotion of beta-cell proliferation, and inhibition of inappropriate glucagon release during hyperglycemia) also made it an attractive target for the treatment of diabetes. However, native GLP-1 is rapidly metabolized by the enzyme dipeptidyl peptidase-4 (DPP-4), so it has a half-life of 1-2 minutes when administered intravenously or around 1 hour when injected subcutaneously. ${ }^{40}$ As a result, the therapeutic utility of the peptide is limited.

Fortunately, a number of potent GLP-1 receptor agonists have been identified. Two such agents, exenatide and liraglutide, have already been approved by the FDA for the treatment of diabetes, and other agents, including taspoglutide and albiglutide, are in various stages of development.

\section{Exenatide}

Exenatide $\left(\right.$ Byetta $\left.^{\circledR}\right)$ is an injectable GLP-1 receptor agonist that is currently approved by the FDA for the treatment of type 2 diabetes, either as monotherapy or as an adjunct to the use of oral antidiabetic agents. It is a synthetic form of exendin-4, a peptide hormone found in the saliva of the lizard Heloderma suspectum, also known as the Gila monster. ${ }^{41}$ Exenatide and the naturally occurring exendin-4 are not full GLP-1 analogs, but they are potent agonists of the human GLP-1 receptor, exhibiting the same antidiabetic effects as native GLP-1. Unlike GLP-1, however, exenatide is not metabolized by the enzyme DPP-4, and its reported half-life is 2.4 hours. Exenatide undergoes renal clearance, and its halflife is therefore prolonged in patients with kidney disease. ${ }^{42}$

\section{Effects on $\mathrm{HbA}_{\mathrm{Ic}}$ and body weight in diabetes}

Exenatide has clearly been shown to improve glycemic control in patients with type 2 diabetes while reducing body weight. In numerous randomized trials lasting up to 52 weeks, treatment with exenatide as monotherapy or as an adjunct to oral antidiabetic agents produced mean reductions in $\mathrm{HbA}_{1 \mathrm{c}}$ of up to $1.4 \%$ and mean weight losses of up to $3.6 \mathrm{~kg}$, as shown in Table $1{ }^{43-53}$ Improvements in both $\mathrm{HbA}_{1 \mathrm{c}}$ and body weight appear to be dose-dependent. ${ }^{43-45}$

In each of the randomized trials shown in Table 1, exenatide-associated weight loss was progressive for the duration of the study, up to 52 weeks. Buse et al recently published interim analyses of two- to three-year data gathered in open-label extension trials following three 30-week double-blind, placebo-controlled trials. ${ }^{53,54}$ In 238 subjects treated with exenatide for at least two years, $\mathrm{HbA}_{1 \mathrm{c}}$ decreased significantly by $1.1 \%$ and body weight decreased significantly by $4.7 \mathrm{~kg}$, on average. ${ }^{54}$ In 217 subjects treated with exenatide for at least three years, $\mathrm{HbA}_{1 \mathrm{c}}$ declined by 
Table I Summary of randomized trials investigating the effects of twice-daily exenatide on $\mathrm{HbA}_{\mathrm{Ic}}$ and body weight in patients with uncontrolled type 2 diabetes

\begin{tabular}{|c|c|c|c|c|c|c|c|c|c|c|}
\hline \multirow[t]{2}{*}{ Study } & \multirow[t]{2}{*}{$\mathbf{n}$} & \multicolumn{3}{|c|}{ Study design } & \multirow{2}{*}{$\begin{array}{l}\text { Duration } \\
\text { of study } \\
\text { (weeks) }\end{array}$} & \multirow{2}{*}{$\begin{array}{l}\text { Concomitant } \\
\text { diabetes } \\
\text { medications }\end{array}$} & \multicolumn{2}{|c|}{$\begin{array}{l}\text { Mean change in } \\
\operatorname{HbA}_{\mathrm{Ic}}(\%)\end{array}$} & \multicolumn{2}{|c|}{$\begin{array}{l}\text { Mean change in } \\
\text { body weight (kg) }\end{array}$} \\
\hline & & Blinding & Control & Design & & & $5 \mu \mathrm{g}$ bid & $10 \mu \mathrm{g}$ bid & $5 \mu \mathrm{g}$ bid & $10 \mu \mathrm{g}$ bid \\
\hline *Buse et $\mathrm{al}^{43}$ & 377 & Triple & Placebo & Parallel & 30 & SU & -0.5 & -0.9 & -0.9 & -1.6 \\
\hline *Kendall et $\mathrm{al}^{44}$ & 733 & Double & Placebo & Parallel & 30 & $M e t+S U$ & -0.6 & -0.8 & -1.6 & -1.6 \\
\hline$*$ DeFronzo et al ${ }^{45}$ & 336 & Triple & Placebo & Parallel & 30 & Met & -0.4 & -0.8 & -1.6 & -2.8 \\
\hline$*$ Heine et $a^{46}$ & 551 & None & $\begin{array}{l}\text { Insulin } \\
\text { glargine }\end{array}$ & Parallel & 26 & Met + SU & NA & -1.1 & NA & -2.3 \\
\hline$*$ Nauck et al ${ }^{47}$ & 501 & None & $\begin{array}{l}\text { Biphasic } \\
\text { insulin } \\
\text { aspart }\end{array}$ & Parallel & 52 & Met $+\mathrm{SU}$ & NA & -1.0 & NA & -2.5 \\
\hline$*$ Zinman et $\mathrm{al}^{48}$ & 233 & Double & Placebo & Parallel & 16 & TZD \pm Met & NA & -0.9 & NA & -2.1 \\
\hline$*$ Barnett et $\mathrm{al}^{49}$ & 138 & None & $\begin{array}{l}\text { Insulin } \\
\text { glargine }\end{array}$ & Crossover & 16 & Met or SU & NA & -1.4 & NA & $\begin{array}{l}-0.4 \text { (on SU) } \\
-2.6 \text { (on Met) }\end{array}$ \\
\hline$*$ Moretto et a $\left.\right|^{50}$ & 232 & Double & Placebo & Parallel & 24 & None & -0.7 & -0.9 & -2.8 & -3.1 \\
\hline${ }^{\circledR}$ Bunck et $\mathrm{a}^{51}$ & 69 & None & $\begin{array}{l}\text { Insulin } \\
\text { glargine }\end{array}$ & Parallel & 52 & Met & NA & -0.8 & NA & -3.6 \\
\hline$*$ Davies et al ${ }^{52}$ & 235 & None & $\begin{array}{l}\text { Insulin } \\
\text { glargine }\end{array}$ & Parallel & 26 & $\begin{array}{l}2 \text { or } 3 \text { oral } \\
\text { agents (Met, SU, } \\
\text { or TZD) }\end{array}$ & NA & -1.2 & NA & -2.7 \\
\hline$*$ Buse et $\mathrm{a}^{53}$ & 464 & None & Liraglutide & Parallel & 26 & Met, SU, or both & NA & -0.8 & NA & -2.9 \\
\hline
\end{tabular}

Notes: *Exenatide was administered at a dose of $5 \mu \mathrm{g}$ bid for 4 weeks and then 5 or $10 \mu \mathrm{g}$ bid for the duration of the study; ${ }^{\natural}$ Exenatide was 5 to $20 \mu \mathrm{g}$ bid or tid, depending upon glycemic control and tolerance; $7 \%$ of volunteers received $5 \mu \mathrm{g}$ bid, $62 \%$ received $10 \mu \mathrm{g}$ bid, and $31 \%$ received doses above $20 \mu \mathrm{g}$ daily.

Abbreviations: $\mathrm{HbA}_{1 \mathrm{c}}$, glycosylated hemoglobin; Met, metformin; NA, not available; SU, sulfonylurea; TZD, thiazolidinedione.

$1.0 \%$ and body weight decreased by $5.3 \mathrm{~kg}$, on average. ${ }^{55}$ As in the original placebo-controlled Phase III trials, ${ }^{43-45}$ significant weight loss occurred in the extension trials despite a lack of specific counseling regarding diet, physical activity, and weight management. Interestingly, there was no apparent weight plateau during follow-up, suggesting that exenatideassociated weight loss is progressive for up to three years.

\section{Other benefits}

A variety of other beneficial metabolic effects have occasionally but inconsistently been observed in diabetic patients treated with exenatide, particularly with longer-term use. These include improvements in systolic and diastolic blood pressure, ${ }^{50,55}$ LDL-cholesterol, ${ }^{43,55}$ HDL-cholesterol, and triglycerides. ${ }^{55}$ Off-label use of exenatide in patients with the metabolic syndrome (but not diabetes) has been reported; in clinical practice, improvements in waist circumference, blood pressure, total cholesterol, and triglycerides have been seen in these patients. ${ }^{56}$

There are little published data about the effects of exenatide on body weight in nondiabetic patients with obesity. At the 2009 Endocrine Society annual meeting, Trautmann et al presented preliminary data from the first randomized, double-blind, placebo-controlled trial of exenatide for weight reduction in nondiabetic adults. ${ }^{57}$ In this study, 152 subjects followed a diet and exercise program and were randomized to receive either exenatide $10 \mu \mathrm{g}$ twice daily or placebo for 24 weeks. At the end of 24 weeks, exenatide-treated subjects experienced a mean weight loss of $5.1 \mathrm{~kg}$ (approximately $4.7 \%$ of initial weight), which was significant compared with a mean loss of $1.6 \mathrm{~kg}$ in placebotreated subjects. Weight loss was progressive throughout this study, with no apparent weight plateau observed at 24 weeks. Several other clinical trials are now underway to investigate the effects of exenatide in nondiabetic patients, including patients with obesity and polycystic ovary syndrome.

\section{Dosing and administration}

The recommended dose of exenatide is $5-10 \mu \mathrm{g}$ injected subcutaneously twice a day before meals. The manufacturer recommends starting at $5 \mu \mathrm{g}$ twice a day for one month (to improve tolerability) and then increasing to $10 \mu \mathrm{g}$ twice a day based on clinical response. Exenatide is currently available as either $5 \mu \mathrm{g}$ or $10 \mu \mathrm{g}$ fixed dose prefilled pens, with each pen containing 60 doses. A long-acting release (LAR) formulation of exenatide has been developed for weekly use and is currently in clinical trials but is not yet approved by the FDA. ${ }^{58,59}$ Initial research suggests that 
$2 \mathrm{mg}$ of exenatide LAR, administered weekly, may improve glycemic control more than twice-daily exenatide, with comparable reductions in body weight. ${ }^{58,60}$ Other formulations of exenatide that are in early phase development include a transdermal patch and nasal spray.

\section{Adverse events}

The most common adverse events experienced with exenatide treatment are gastrointestinal in nature. In the Phase III trials of exenatide for type 2 diabetes, nausea was the most common adverse event, occurring in up to $51 \%$ of subjects treated with $10 \mu \mathrm{g}$ bid. ${ }^{43-45}$ Vomiting and diarrhea occurred in up to $14 \%$ and $17 \%$ of exenatide-treated subjects, respectively. In most patients, these gastrointestinal effects are mild or moderate and rarely lead to drug discontinuation. In the Phase III trials, less than $6 \%$ of subjects experienced severe nausea, and less than $4 \%$ of subjects discontinued treatment due to nausea. Typically, the incidence of nausea is greatest during the first two months of therapy and declines thereafter. Interestingly, nausea does not seem to contribute significantly to the drug's effects on body weight, because patients who never experience nausea lose similar amounts of weight as those who do. ${ }^{43-45}$ Nausea appears to occur less frequently with the LAR formulation in development, and patient satisfaction may be greater with once-weekly rather than twice-daily dosing. ${ }^{58,61}$ Exenatide is not recommended for use in patients with gastroparesis or other disorders that significantly reduce gastrointestinal motility.

Since the approval of exenatide by the FDA in 2005, there have been postmarketing reports of pancreatitis in exenatidetreated patients. ${ }^{62-64}$ Most cases were apparently mild or moderate in severity, resolving completely upon cessation of the drug. However, rare cases of fatal and nonfatal hemorrhagic or necrotizing pancreatitis have also been reported. Therefore, upon initiation or dose escalation, all patients should be informed about the potential risks and symptoms of pancreatitis. Furthermore, the use of exenatide should be avoided in patients with a history of pancreatitis or significant risk factors for pancreatitis, such as active alcohol abuse, severe hypertriglyceridemia, or symptomatic gallstones.

Coadministration of exenatide and sulfonylureas has been associated with an increased risk of hypoglycemia. In a Phase III trial, up to $36 \%$ of patients treated with both exenatide and a sulfonylurea experienced mild to moderate hypoglycemia, compared with just $3 \%$ in the placebo group, who continued to have poor glycemic control on a sulfonylurea alone. ${ }^{43}$ However, when used either as monotherapy or as an adjunct to metformin, exenatide does not increase the risk of hypoglycemia. ${ }^{45,50}$ In these circumstances, hypoglycemia would not be expected to occur, because GLP-1 receptor agonism modulates insulin and glucagon secretion in a glucose-dependent manner.

Development of antiexenatide antibodies has been observed in up to $49 \%$ of subjects treated with exenatide for 30 weeks. ${ }^{4-45}$ Fortunately, antibody formation does not affect glycemic control and does not appear to increase the risk of adverse events. Other common but typically mild adverse events observed in the Phase III trials include dizziness, jitteriness, and headaches.

\section{Contraindications}

Exenatide is not recommended for use in patients with severe renal impairment (ie, creatinine clearance $<30 \mathrm{~mL} / \mathrm{min}$ ), including those requiring dialysis, and caution is advised in patients with a history of renal transplant or moderate renal impairment (creatinine clearance $30-50 \mathrm{~mL} / \mathrm{min}$ ). There have been postmarketing reports of increased serum creatinine, renal impairment, acute renal failure, and worsening of chronic renal failure, sometimes requiring dialysis or transplantation. ${ }^{64,65}$ In some cases, affected patients were taking other pharmacologic agents known to affect renal function, such as angiotensin-converting enzyme inhibitors, diuretics, or nonsteroidal anti-inflammatory agents. In some cases, affected patients had nausea, vomiting, or decreased fluid intake, which may have contributed to their worsening renal function.

\section{Drug interactions}

Significant drug interactions are relatively rare with exenatide. There have been postmarketing reports of prolonged prothrombin time and increased International Normalized Ratio, sometimes associated with bleeding, in patients on warfarin and exenatide. ${ }^{64}$ Since exenatide delays gastric emptying, it may affect the extent and rate of absorption of oral medications. Therefore, medications that require a threshold concentration for efficacy, such as oral contraceptives and antibiotics, should be taken at least one hour before administration of exenatide. Exenatide has not been studied for use with insulin, and the manufacturer does not recommend concomitant use of these agents. However, off-label use of the combination has been reported. ${ }^{66-68}$

\section{Patient satisfaction and adherence}

Patient adherence to exenatide therapy is generally good, but route of administration, side effects, cost, and insurance coverage can impact on adherence. Some patients may 
initially be reluctant to use injectable medications, but the fixed-dose prefilled pen makes administration simple and convenient. Furthermore, many patients report that injections using fine-gauge pen needles are less painful than finger sticks for home blood glucose monitoring. Studies suggest that patients treated with twice-daily exenatide experience significant improvements in treatment satisfaction and reductions in diabetes-related symptoms, including fatigue and symptoms of hypo- and hyperglycemia. ${ }^{61,69}$ However, in the Phase III clinical trials of 30 weeks' duration, 4\%-10\% of exenatide-treated subjects withdrew due to treatmentemergent adverse events, such as nausea. ${ }^{43-45}$ In clinical practice, discontinuation due to adverse events may be slightly more common. ${ }^{70}$ Cost may be another barrier to treatment, because the retail price of exenatide can approach $\$ 300$ per month. Fortunately, in recent years, more third-party payers have included exenatide in their formularies, but some require prior authorization, documentation of inadequate glycemic control with oral agents, or higher patient co-pays. Off-label use (such as with concomitant insulin therapy or in patients without type 2 diabetes) may not be a covered benefit.

\section{Liraglutide}

Liraglutide $\left(\right.$ Victoza $\left.^{\circledR}\right)$ is an injectable GLP-1 receptor agonist currently approved by the FDA for the treatment of type 2 diabetes not controlled by lifestyle modification or oral antidiabetic therapy. Unlike exenatide, liraglutide is a GLP-1 analog, sharing 97\% amino acid sequence homology with native GLP-1. Important modifications to the peptide structure serve to delay its absorption from subcutaneous tissue, make it resistant to DPP-4 degradation, and enable reversible binding to albumin. ${ }^{71}$ Over $98 \%$ of liraglutide is bound to albumin, and free liraglutide is metabolized by endogenous peptidases. Liraglutide does not undergo significant renal or hepatic clearance. As a result, its reported half-life after subcutaneous administration is 13 hours.

\section{Effects on $\mathrm{HbA}_{\mathrm{Ic}}$ and body weight in diabetes}

Liraglutide has been shown to improve glycemic control in patients with type 2 diabetes while reducing body weight. In randomized trials lasting up to 52 weeks, treatment with $1.2-1.8 \mathrm{mg}$ of liraglutide daily as monotherapy or as an adjunct to oral antidiabetic agents produced mean reductions in $\mathrm{HbA}_{1 \mathrm{c}}$ of up to $1.5 \%$ and mean weight losses of up to $3.2 \mathrm{~kg}$, as shown in Table 2. ${ }^{53,72-77}$ Earlier trials utilizing lower doses of liraglutide typically reported smaller improvements in $\mathrm{HbA}_{1 \mathrm{c}}$ and body weight. ${ }^{78,79}$ In a head-to-head randomized trial sponsored by Novo Nordisk, $1.8 \mathrm{mg}$ liraglutide once daily produced significantly greater reductions in $\mathrm{HbA}_{1 \mathrm{c}}$ than $10 \mu \mathrm{g}$ exenatide twice daily. ${ }^{53}$

In the clinical trials shown in Table 2, weight loss occurred with liraglutide despite a lack of specific counseling regarding diet, physical activity, and weight management. In some of these trials, weight loss appears to have reached a plateau by $12-20$ weeks of treatment, ${ }^{73,75,77}$ whereas in another study,

Table 2 Summary of randomized trials investigating the effects of once-daily liraglutide on $\mathrm{HbA}_{\mathrm{lc}}$ and body weight in patients with uncontrolled type 2 diabetes

\begin{tabular}{|c|c|c|c|c|c|c|c|c|c|c|}
\hline \multirow[t]{2}{*}{ Study } & \multirow[t]{2}{*}{$\mathbf{n}$} & \multicolumn{3}{|c|}{ Study design } & \multirow[t]{2}{*}{$\begin{array}{l}\text { Duration } \\
\text { of study } \\
\text { (weeks) }\end{array}$} & \multirow[t]{2}{*}{$\begin{array}{l}\text { Concomitant } \\
\text { diabetes } \\
\text { medications }\end{array}$} & \multicolumn{2}{|c|}{$\begin{array}{l}\text { Mean change } \\
\text { in } \mathrm{HbA}_{\mathrm{Ic}}(\%)\end{array}$} & \multicolumn{2}{|c|}{$\begin{array}{l}\text { Mean change } \\
\text { in body weight } \\
(\mathrm{kg})\end{array}$} \\
\hline & & Blinding & Control & Design & & & $\begin{array}{l}1.2 \mathrm{mg} \\
\text { daily }\end{array}$ & $\begin{array}{l}1.8 \mathrm{mg} \\
\text { daily }\end{array}$ & $\begin{array}{l}1.2 \mathrm{mg} \\
\text { daily }\end{array}$ & $\begin{array}{l}1.8 \mathrm{mg} \\
\text { daily }\end{array}$ \\
\hline$*$ Vilsboll et al ${ }^{72}$ & 165 & Double & Placebo & Parallel & 14 & None & -1.4 & -1.45 & NA & -3.0 \\
\hline$* * \neq$ Garber et $\mathrm{al}^{73}$ & 746 & Double & Glimepiride & Parallel & 52 & $0-1$ oral agents & -0.8 & -1.1 & -2.0 & -2.5 \\
\hline${ }^{\infty}$ Nauck et $\mathrm{al}^{74}$ & 1091 & Double & $\begin{array}{l}\text { Placebo or } \\
\text { glimepiride }\end{array}$ & Parallel & 26 & Met & -1.0 & -1.0 & -2.6 & -2.8 \\
\hline$* *$ Zinman et $\mathrm{a}^{75}$ & 533 & Double & Placebo & Parallel & 26 & Met + rosiglitazone & -1.5 & -1.5 & -1.0 & -2.0 \\
\hline${ }^{\infty}$ Marre et $\mathrm{al}^{76}$ & 1041 & Double & $\begin{array}{l}\text { Placebo or } \\
\text { rosiglitazone }\end{array}$ & Parallel & 26 & Glimepiride & -1.1 & -1.1 & +0.3 & -0.2 \\
\hline$* *$ Buse et al ${ }^{53}$ & 464 & None & Exenatide & Parallel & 26 & Met, SU, or both & NA & -1.1 & NA & -3.2 \\
\hline$* *$ Russell-Jones et al ${ }^{77}$ & 581 & Mixed $\$$ & $\begin{array}{l}\text { Placebo or } \\
\text { insulin glargine }\end{array}$ & Parallel & 26 & Met + glimepiride & NA & -1.3 & NA & -1.8 \\
\hline
\end{tabular}

Notes: *Liraglutide doses were $0.65 \mathrm{mg}, 1.25 \mathrm{mg}$ or $1.9 \mathrm{mg}$ daily $(0.65 \mathrm{mg}$ results not reported here); ** In these trials, liraglutide was initiated at a dose of $0.6 \mathrm{mg}$ daily for

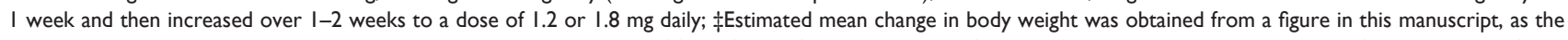
mean value was not reported; $\infty$ Liraglutide was administered at doses of $0.6,1.2$, or $1.8 \mathrm{mg}$ daily. Results from the $0.6 \mathrm{mg}$ arm are not shown here. Subjects in the 1.2 and $1.8 \mathrm{mg}$ dose arms underwent a dose-escalation period for $2-3$ weeks after randomization; $\S$ In this trial, patients were randomly assigned to liraglutide, placebo, or open-label insulin glargine.

Abbreviations: $\mathrm{HbA}_{\mathrm{Ic}}$, glycosylated hemoglobin; Met, metformin; SU, sulfonylurea. 
weight loss was progressive for up to 26 weeks. ${ }^{53}$ Treatment with liraglutide has been shown to reduce visceral as well as subcutaneous adiposity in patients with type 2 diabetes. ${ }^{80}$

\section{Other benefits}

In addition to improvements in glycemic control and body weight, liraglutide may have other metabolic benefits in patients with diabetes. Significant reductions in systolic blood pressure ${ }^{73-75}$ and triglycerides ${ }^{53,72}$ have been observed with liraglutide in some studies. A recent meta-analysis of six Phase III clinical trials, reported at the 2009 annual meeting of the Endocrine Society, suggests that liraglutide also lowers total and LDL-cholesterol levels and reduces the prevalence of the metabolic syndrome in patients with diabetes. ${ }^{81}$ Furthermore, reductions in plasminogen activator inhibitor 1, an inflammatory biomarker, and B-type natriuretic peptide, a biomarker associated with cardiovascular risk, have been observed in liraglutide-treated patients with diabetes. ${ }^{82}$

Liraglutide is currently being studied as a potential treatment for obesity in patients without diabetes, although it is not yet FDA-approved for this indication. In a Phase II trial of 20 weeks' duration, 564 nondiabetic obese subjects were randomly assigned to one of four doses of liraglutide $(1.2,1.8,2.4$, or $3.0 \mathrm{mg}$ daily), placebo, or orlistat $120 \mathrm{mg}$ three times daily. ${ }^{83}$ Approximately one-third of subjects had prediabetes at the time of randomization. During the trial, subjects were instructed to consume a low-fat, $500 \mathrm{kcal} /$ day deficit diet and to increase physical activity as measured using pedometers. Subjects randomized to liraglutide lost significantly more weight than those assigned to either placebo or orlistat. Mean weight loss was 4.8, 5.5, 6.3, and $7.2 \mathrm{~kg}$ for the $1.2,1.8,2.4$, and $3.0 \mathrm{mg}$ doses of liraglutide, respectively, as compared with $2.8 \mathrm{~kg}$ with placebo and $4.1 \mathrm{~kg}$ with orlistat. In addition, the prevalence of prediabetes was significantly reduced in liraglutide-treated subjects, as compared with those on placebo or orlistat. Improvements in blood pressure were also seen with liraglutide, although these were not consistently greater than improvements seen with placebo or orlistat. In an interim analysis of data from an ongoing 84-week, open-label extension of this Phase II trial, Finer et al reported similar findings, including a reduced prevalence of prediabetes and some improvements in blood pressure with liraglutide. ${ }^{84}$

\section{Dosing and administration}

For the treatment of type 2 diabetes, the recommended dose of liraglutide is 1.2 to $1.8 \mathrm{mg}$ injected subcutaneously once daily at any time of day. The manufacturer recommends starting at $0.6 \mathrm{mg}$ daily for one week to reduce gastrointestinal symptoms during initial titration. The dose should then be increased to 1.2 or $1.8 \mathrm{mg}$ daily, based on clinical response. Liraglutide is currently available as a fixed-dose, prefilled pen delivering doses of $0.6,1.2$, or $1.8 \mathrm{mg}$.

\section{Adverse events}

As with exenatide, the most common adverse events experienced with liraglutide treatment are gastrointestinal in nature. In Phase III trials, nausea was the most common adverse event, occurring in up to $40 \%$ of subjects treated with liraglutide. ${ }^{53,72-77}$ Data from one head-to-head trial suggest that nausea is less persistent with liraglutide than with exenatide. ${ }^{53}$ Researchers reported that the incidence of nausea is greatest during the first month of therapy and declines thereafter. Vomiting and diarrhea occurred in up to $12 \%$ and $21 \%$ of liraglutide-treated subjects, respectively. In most subjects, these gastrointestinal effects were mild or moderate, typically leading to drug withdrawal in less than $4 \%$ of subjects on $1.2 \mathrm{mg}$ daily or up to $11 \%$ of subjects on $1.8 \mathrm{mg}$ daily.

Small but statistically significant increases in heart rate (eg, 2-4 beats per minute) have been observed in some of the Phase III clinical trials. ${ }^{73,76}$ In the head-to-head study of liraglutide versus exenatide, increases in heart rate occurred in both groups, although the change was significant only for liraglutide. ${ }^{53}$ Development of anti-liraglutide antibodies has been observed in up to $13 \%$ of treated subjects. ${ }^{76,77}$ Antibody formation does not appear to affect drug efficacy in most patients, but efficacy may be compromised in rare patients with extremely high antibody levels. ${ }^{71}$ Patients who develop anti-liraglutide antibodies may be slightly more likely to experience upper respiratory tract infections than antibody-negative patients. Other common but typically mild adverse events observed in the Phase III trials include headaches and fatigue.

Pancreatitis has been observed in the Phase III clinical trials of liraglutide, although it is rare. ${ }^{71}$ Therefore, liraglutide should be used cautiously in patients with a history of pancreatitis or significant risk factors for pancreatitis, such as active alcohol abuse, severe hypertriglyceridemia, or symptomatic gallstones.

Combination therapy with liraglutide and an insulin secretagogue may increase the risk of hypoglycemia. In clinical trials, up to $33 \%$ of patients treated with both liraglutide and a sulfonylurea experienced mild to moderate hypoglycemia..$^{53,76,77}$ However, when used either as monotherapy or as an adjunct to metformin, liraglutide does not increase the risk of hypoglycemia. ${ }^{72,74}$ 


\section{Contraindications}

Treatment with liraglutide has been associated with an increased risk of benign and malignant thyroid C-cell tumors in rodents. ${ }^{71}$ The clinical relevance of this finding is unknown, because there has been no reported increase in thyroid C-cell tumors, such as medullary thyroid carcinoma, in human subjects. Nevertheless, liraglutide is contraindicated for use in patients with a personal or family history of medullary thyroid carcinoma or multiple endocrine neoplasia syndrome type 2. Rare cases of papillary thyroid carcinoma have been reported in liraglutide-treated subjects. In most cases, these were reportedly small tumors discovered as a result of protocol-specified thyroid surveillance testing, which is not routinely recommended in clinical practice.

Since liraglutide does not undergo significant renal or hepatic clearance, no dose adjustment is recommended in patients with renal or hepatic impairment. However, there are limited safety data regarding the use of liraglutide in these patients, so it should be used cautiously.

\section{Drug interactions}

Like exenatide, liraglutide delays gastric emptying, so may affect the extent and rate of absorption of oral medications. However, no clinically significant effects have been found in clinical pharmacology trials conducted by the manufacturer. ${ }^{71}$ Liraglutide has not been studied for use with insulin, and concomitant use of these agents is not recommended.

\section{Patient satisfaction and adherence}

As with exenatide, the route of administration, side effects, cost, and insurance coverage would be expected to impact patient adherence with liraglutide treatment. In the headto-head trial of once-daily liraglutide versus twice daily exenatide, treatment satisfaction was significantly greater in the liraglutide group. ${ }^{53}$ Liraglutide's dosing schedule (once daily at any time of day) is certainly more convenient than exenatide's current dosing schedule (twice daily before meals). However, approval of an LAR formulation of exenatide for weekly use would likely increase patient satisfaction even more. Since liraglutide has only recently been approved by the FDA, insurance coverage is likely to be an issue for some patients. The retail price of liraglutide can approach $\$ 400$ a month for the highest dose.

\section{Other GLP-I receptor agonists in development}

In the future, other GLP-1 receptor agonists may also be available, besides exenatide and liraglutide. Taspoglutide is a GLP-1 analog that is currently under study by Roche for the treatment of type 2 diabetes. ${ }^{85}$ A sustained-release formulation has been developed for weekly use. Albiglutide is a long-acting GLP-1 receptor agonist which is under study by GlaxoSmithKline for the treatment of type 2 diabetes. ${ }^{86}$ If approved by the FDA, it would likely be administered once weekly.

Another intriguing strategy in the early phase of development is the employment of peptides which act as dual agonists of both GLP-1 and glucagon receptors, like the naturally-occurring peptide, oxyntomodulin. In rodents, GLP-1 and glucagon receptor coagonists appear to increase energy expenditure, decrease food intake, reduce body weight, improve dyslipidemia, reduce hepatic steatosis, and improve glycemic control. ${ }^{87,88}$

\section{Conclusion}

GLP-1 receptor agonists have proven to be a very useful option in the treatment of type 2 diabetes, particularly in overweight and obese patients. Treatment-associated weight loss can be significant, which sets this class of medications apart from most other antidiabetic agents. In the future, GLP-1 receptor agonists may also play a role in the management of nondiabetic patients with obesity. Given the recent increase in the prevalence of obesity and the paucity of effective pharmacologic therapies, the development of new agents to treat obesity is of critical importance. GLP-1 receptor agonists may have utility, either alone or as part of a multipronged approach to the pharmacologic management of obesity. Unfortunately, the same issues that limit the use of currently approved weight loss medications (ie, adverse effects, contraindications, limited coverage by third-party payers, and cost) may affect GLP-1 agonists as well.

\section{Disclosure}

The authors report no conflicts of interest in this work.

\section{References}

1. Flegal KM, Carroll MD, Ogden CL, Curtin LR. Prevalence and trends in obesity among US adults, 1999-2008. JAMA. 2010;303(3):235-241.

2. Kuczmarski RJ, Flegal KM, Campbell SM, Johnson CL. Increasing prevalence of overweight among US adults: The National Health and Nutrition Examination Surveys, 1960 to 1991. JAMA. 1994;272: 205-211.

3. Dansinger ML, Gleason JA, Griffith JL, Selker HP, Schaefer EJ. Comparison of the Atkins, Ornish, Weight Watchers, and Zone diets for weight loss and heart disease risk reduction: A randomized trial. JAMA. 2005; 293:43-53.

4. Brinkworth GD, Wycherley TP, Noakes M, Clifton PM. Reductions in blood pressure following energy restriction for weight loss do not rebound after re-establishment of energy balance in overweight and obese subjects. Clin Exp Hypertens. 2008;30:385-396. 
5. Hamman RF, Wing RR, Edelstein SL, et al. Effect of weight loss with lifestyle intervention on risk of diabetes. Diabetes Care. 2006;29: 2102-2107.

6. Wadden TA, Berkowitz RI, Womble LG, et al. Randomized trial of lifestyle modification and pharmacotherapy for obesity. $N$ Engl J Med. 2005;353:2111-2120.

7. Richelsen BR, Tonstad S, Rassner S, et al. Effect of orlistat on weight regain and cardiovascular risk factors following a very-low-energy diet in abdominally obese patients. Diabetes Care. 2007;30:27-32.

8. Arterburn D, Crane P, Veenstra D. The efficacy and safety of sibutramine for weight loss: A systematic review. Arch Intern Med. 2004;164:994-1003.

9. Hutton B, Fergusson D. Changes in body weight and serum lipid profile in obese patients treated with orlistat in addition to a hypocaloric diet: A systematic review of randomized clinical trials. Am J Clin Nutr. 2004; 80:1461-1468.

10. Padwal R, Li S, Lau D. Long-term pharmacotherapy for obesity and overweight. Cochrane Database Syst Rev. 2003;4:CD004094.

11. Vettor R, Serra R, Fabris R, Pagano C, Federspil G. Effect of sibutramine on weight management and metabolic control in Type 2 diabetes. Diabetes Care. 2005;28:942-949.

12. Li Z, Maglione M, Tu W, et al. Meta-analysis: Pharmacologic treatment of obesity. Ann Intern Med. 2005;142:532-546.

13. Eissele R, Goke R, Willemer S, et al. Glucagon-like peptide-1 cells in the gastrointestinal tract and pancreas of rat, pig and man. Eur J Clin Invest. 1992;22:283-291.

14. Mortensen K, Christensen LL, Holst JJ, Orskov C. GLP-1 and GIP are colocalized in a subset of endocrine cells in the small intestine. Regul Pept. 2003;114:189-196.

15. Hermann C, Goke R, Richter G, Fehmann H, Arnold R, Goke B Glucagon-like peptide-1 and glucose-dependent insulin-releasing polypeptide plasma levels in response to nutrients. Digestion. 1995;56:117-126.

16. Holst J. The physiology of glucagon-like peptide 1. Physiol Rev. 2007; 87:1409-1439.

17. Nakagawa A, Satake H, Nakabayashi H, et al. Receptor gene expression of glucagon-like peptide-1, but not glucose-dependent insulinotropic polypeptide, in rat nodose ganglion cells. Auton Neurosci. 2004; 110:36-43.

18. Bucinskaite V, Tolessa T, Pedersen J, et al. Receptor-mediated activation of gastric vagal afferents by glucagon-like peptide-1 in the rat. Neurogastroenterol Motil. 2009;21:978-e78.

19. Doyle M, Egan J. Mechanisms of action of glucagon-like peptide 1 in the pancreas. Pharmacol Ther. 2007;113:546-593.

20. Hare K, Knop F, Asmar M, et al. Preserved inhibitory potency of GLP-1 on glucagon secretion in Type 2 diabetes mellitus. J Clin Endocrinol Metab. 2009;94:4679-4687.

21. Göke R, Larsen P, Mikkelsen J, Sheikh S. Distribution of GLP-1 binding sites in the rat brain: Evidence that exendin-4 is a ligand of brain GLP-1 binding sites. Eur J Neurosci. 1995;7:2294-2300.

22. Kastin A, Akerstrom V, Pan W. Interactions of glucagon-like peptide-1 (GLP-1) with the blood-brain barrier. J Mol Neurosci. 2002;18:7-14.

23. Hassan M, Eskilsson A, Nilsson C, et al. In vivo dynamic distribution of 131I-glucagon-like peptide-1 (7-36) amide in the rat studied by gamma camera. Nucl Med Biol. 1999;26:413-420.

24. Pannacciulli N, Le D, Salbe A, et al. Postprandial glucagon-like peptide-1 (GLP-1) response is positively associated with changes in neuronal activity of brain areas implicated in satiety and food intake regulation in humans. Neuroimage. 2007;35:511-517.

25. Abbott CR, Monteiro M, Small CJ, et al. The inhibitory effects of peripheral administration of peptide YY3-36 and glucagon-like peptide- 1 on food intake are attenuated by ablation of the vagal-brainstemhypothalamic pathway. Brain Res. 2005;1044:127-131.

26. Turton M, O'Shea D, Gunn I, et al. A role for glucagon-like peptide-1 in the central regulation of feeding. Nature. 1996;379:69-72.

27. Hwa JJ, Ghibaudi L, Williams P, Witten MB, Tedesco R, Strader CD. Differential effects of intracerebroventricular glucagon-like peptide-1 on feeding and energy expenditure regulation. Peptides. 1998;19:869-875.
28. Flint A, Raben A, Astrup A, Holst J. Glucagon-like peptide 1 promotes satiety and suppresses energy intake in humans. J Clin Invest. 1998;101:515-520.

29. Verdich C, Flint A, Gutzwiller J, et al. A meta-analysis of the effect of glucagon-like peptide-1 (7-36) amide on ad libitum energy intake in humans. J Clin Endocrinol Metab. 2001;86:4382-4389.

30. Meeran K, O'Shea D, Edwards CMB, et al. Repeated intracerebroventricular administration of glucagon-like peptide-1-(7-36) amide or exendin-(9-39) alters body weight in the rat. Endocrinology. 1999; 140:244-250.

31. Zander M, Madsbad S, Madsen JL, Holst JJ. Effect of 6-week course of glucagon-like peptide 1 on glycaemic control, insulin sensitivity, and [beta]-cell function in type 2 diabetes: A parallel-group study. Lancet. 2002;359:824-830.

32. Scrocchi L, Brown T, MaClusky N, et al. Glucose intolerance but normal satiety in mice with a null mutation in the glucago-like peptide 1 receptor gene. Nat Med. 1996;2:1254-1258.

33. Osaka T, Endo M, Yamakawa M, Inoue S. Energy expenditure by intravenous administration of glucagon-like peptide-1 mediated by the lower brainstem and sympathoadrenal system. Peptides. 2005;26: 1623-1631.

34. Pannacciulli N, Bunt JC, Koska J, Bogardus C, Krakoff J. Higher fasting plasma concentrations of glucagon-like peptide 1 are associated with higher resting energy expenditure and fat oxidation rates in humans. Am J Clin Nutr. 2006;84:556-560.

35. Shalev A, Holst J, Keller U. Effects of glucagon-like peptide 1 (7-36 amide) on whole-body protein metabolism in healthy man. Eur J Clin Invest. 1997;27:10-16.

36. Flint A, Raben A, Ersboll A, Holst J, Astrup A. The effect of physiological levels of glucagon-like peptide-1 on appetite, gastric emptying, energy and substrate metabolism in obesity. Int J Obes Relat Metab Disord. 2001;25:781-792.

37. Flint A, Raben A, Rehfeld J, Holst J, Astrup A. The effect of glucagonlike peptide-1 on energy expenditure and substrate metabolism in humans. Int J Obes Relat Metab Disord. 2000;24:288-298.

38. Ranganath L, Beety J, Morgan L, Wright J, Howland R, Marks V. Attenuated GLP-1 secretion in obesity: Cause or consequence? Gut. 1996;38:916-919.

39. Verdich C, Toubro S, Buemann B, Madsen J, Holst J, Astrup A. The role of postprandial releases of insulin and incretin hormones in mealinduced satiety - effect of obesity and weight reduction. Int J Obes. 2001;25:1206-1214

40. Vilsboll T, Agerso H, Krarup T, Holst J. Similar elimination rates of glucagon-like peptide- 1 in obese Type 2 diabetic patients and healthy subjects. J Clin Endocrinol Metab. 2003;88:220-224.

41. Eng J, Kleinman WA, Singh L, Singh G, Raufman JP. Isolation and characterization of exendin-4, an exendin-3 analogue, from Heloderma suspectum venom. Further evidence for an exendin receptor on dispersed acini from guinea pig pancreas. J Biol Chem. 1992;267:7402-7405.

42. Linnebjerg H, Kothare P, Park S, et al. Effect of renal impairment on the pharmacokinetics of exenatide. Br J Clin Pharmacol. 2007;64: 317-327.

43. Buse J, Henry R, Han J, Kim D, Fineman M, Baron A, Group E-CS. Effects of exenatide (exendin-4) on glycemic control over 30 weeks in sulfonylurea-treated patients with Type 2 diabetes. Diabetes Care. 2004;27:2628-2635

44. Kendall D, Riddle M, Rosenstock J, et al. Effects of exenatide (exendin-4) on glycemic control over 30 weeks in patients with Type 2 diabetes treated with metformin and a sulfonylurea. Diabetes Care. 2005;28:1083-1091.

45. DeFronzo R, Ratner R, Han J, Kim D, Fineman M, Baron A. Effects of exenatide (exendin-4) on glycemic control and weight over 30 weeks in metformin-treated patients with type 2 diabetes. Diabetes Care. 2005;28:1092-1100.

46. Heine RJ, Van Gaal LF, Johns D, Mihm MJ, Widel MH, Brodows RG. Exenatide versus insulin glargine in patients with suboptimally controlled Type 2 diabetes. Ann Intern Med. 2005;143:559-569. 
47. Nauck M, Duran S, Kim D, et al. A comparison of twice-daily exenatide and biphasic insulin aspart in patients with Type 2 diabetes who were suboptimally controlled with sulfonylurea and metformin: A noninferiority study. Diabetologia. 2007;50:259-267.

48. Zinman B, Hoogwerf B, Durán García S, et al. The effect of adding exenatide to a thiazolidinedione in suboptimally controlled Type 2 diabetes: A randomized trial. Ann Intern Med. 2007;146:477-485.

49. Barnett A, Burger J, Johns D, et al. Tolerability and efficacy of exenatide and titrated insulin glargine in adult patients with Type 2 diabetes previously uncontrolled with metformin or a sulfonylurea: A multinational, randomized, open-label, two-period, crossover noninferiority trial. Clin Ther. 2007;29:2333-2348.

50. Moretto TJ, Milton DR, Ridge TD, et al. Efficacy and tolerability of exenatide monotherapy over 24 weeks in antidiabetic drug-naive patients with type 2 diabetes: A randomized, double-blind, placebocontrolled, parallel-group study. Clin Ther. 2008;30:1448-1460.

51. Bunck M, Diamant M, Cornér A, et al. One-year treatment with exenatide improves beta-cell function, compared with insulin glargine, in metformin-treated Type 2 diabetic patients: A randomized, controlled trial. Diabetes Care. 2009;32:762-768.

52. Davies M, Donnelly R, Barnett A, Jones S, Nicolay C, Kilcoyne A. Exenatide compared with long-acting insulin to achieve glycaemic control with minimal weight gain in patients with Type 2 diabetes: Results of the Helping Evaluate Exenatide in patients with diabetes compared with Long-Acting insulin (HEELA) study. Diabetes Obes Metab. 2009;11:1153-1162.

53. Buse JB, Rosenstock J, Sesti G, et al. Liraglutide once a day versus exenatide twice a day for Type 2 diabetes: A 26-week randomised, parallel-group, multinational, open-label trial (LEAD-6). Lancet. 2009;374:39-47.

54. Buse JB, Klonoff DC, Nielsen LL, et al. Metabolic effects of two years of exenatide treatment on diabetes, obesity, and hepatic biomarkers in patients with Type 2 diabetes: An interim analysis of data from the openlabel, uncontrolled extension of three double-blind, placebo-controlled trials. Clin Ther. 2007;29:139-153.

55. Klonoff DC, Buse JB, Nielsen LL, et al. Exenatide effects on diabetes, obesity, cardiovascular risk factors and hepatic biomarkers in patients with Type 2 diabetes treated for at least 3 years. Curr Med Res Opin. 2008;24:275-286.

56. Bhushan R, Elkind-Hirsch KE, Bhushan M, Butler W, Duncan K, Marrioneaux O. Exenatide use in the management of metabolic syndrome: A retrospective database study. Endocr Pract. 2009;14:993-999.

57. Trautmann M, Northrup J, Glass L, Cao D, Holcombe J. OR14-1: Exenatide treatment added to a lifestyle modification program was associated with body weight reduction in obese patients. Abstract presented at the 2009 annual meeting of the Endocrine Society. Washington DC, June 10-13, 2009.

58. Drucker DJ, Buse JB, Taylor K, et al. Exenatide once weekly versus twice daily for the treatment of Type 2 diabetes: A randomised, openlabel, non-inferiority study. Lancet. 2008;372:1240-1250.

59. Kim D, MacConell L, Zhuang D, et al. Effects of once-weekly dosing of a long-acting release formulation of exenatide on glucose control and body weight in subjects with Type 2 diabetes. Diabetes Care. 2007;30:1487-1493.

60. Buse JB, Drucker DJ, Taylor KL, et al. DURATION-1: Exenatide once weekly produces sustained glycemic control and weight loss over 52 weeks. Diabetes Care. March 9, 2010. [Epub ahead of print].

61. Best JH, Boye KS, Rubin RR, Cao D, Kim TH, Peyrot M. Improved treatment satisfaction and weight-related quality of life with exenatide once weekly or twice daily. Diabet Med. 2009;26(7):722-728.

62. Bain SC, Stephens JW. Exenatide and pancreatitis: An update. Expert Opin Drug Saf. 2008;7(6):643-644.

63. Ayoub W, Kumar A, Naguib H, Taylor H. Exenatide-induced acute pancreatitis. Endocr Pract. 2010;16:80-83.

64. Byetta package insert. Amylin Pharmaceuticals and Eli Lilly Co. Available at: www.byetta.com. Accessed on March 15, 2010.
65. Weise WJ, Sivanandy MS, Block CA, Comi RJ. Exenatide-associated ischemic renal failure. Diabetes Care. 2009;32:e22-e23.

66. Viswanathan P, Chaudhuri A, Bhatia R, Al-Atrash F, Mohanty P, Dandona P. Exenatide therapy in obese patients with Type 2 diabetes mellitus treated with insulin. Endocr Pract. 2007;13:444-450.

67. Sheffield C, Kane M, Busch R, Bakst G, Abelseth J, Hamilton R. Safety and efficacy of exenatide in combination with insulin in patients with Type 2 diabetes mellitus. Endocr Pract. 2008;14:285-292.

68. Yoon NM, Cavaghan MK, Brunelle RL, Roach P. Exenatide added to insulin therapy: A retrospective review of clinical practice over two years in an academic endocrinology outpatient setting. Clin Ther. 2009; 31:1511-1523.

69. Secnik Boye K, Matza L, Oglesby A, et al. Patient-reported outcomes in a trial of exenatide and insulin glargine for the treatment of Type 2 diabetes. Health Qual Life Outcomes. 2006;4:80.

70. King AB, Wolfe G, Healy S. Clinical observations of exenatide treatment. Diabetes Care. 2006;29(8):1984.

71. Victoza ${ }^{\circledR}$ package insert. Novo Nordisk. Available from: www.victoza. com. Accessed on Mar 15, 2010.

72. Vilsboll T, Zdravkovic M, Le-Thi T, et al. Liraglutide, a long-acting human glucagon-like peptide-1 analog, given as monotherapy significantly improves glycemic control and lowers body weight without risk of hypoglycemia in patients with Type 2 diabetes. Diabetes Care. 2007;30:1608-1610.

73. Garber A, Henry R, Ratner R, Garcia-Hernandez PA, et al. Liraglutide versus glimepiride monotherapy for Type 2 diabetes (LEAD-3 Mono): A randomised, 52-week, Phase III, double-blind, parallel-treatment trial. Lancet. 2009;373:473-481.

74. Nauck M, Frid A, Hermansen K, et al. Efficacy and safety comparison of liraglutide, glimepiride, and placebo, all in combination with metformin, in Type 2 diabetes. Diabetes Care. 2009;32:84-90.

75. Zinman B, Gerich J, Buse JB, et al. Efficacy and safety of the human glucagon-like peptide-1 analog liraglutide in combination with metformin and thiazolidinedione in patients with Type 2 diabetes (LEAD-4 Met + TZD). Diabetes Care. 2009;32:1224-1230.

76. Marre M, Shaw J, Brändle M, et al. Liraglutide, a once-daily human GLP-1 analogue, added to a sulphonylurea over 26 weeks produces greater improvements in glycaemic and weight control compared with adding rosiglitazone or placebo in subjects with Type 2 diabetes (LEAD-1 SU). Diabet Med. 2009;26:268-278.

77. Russell-Jones D, Vaag A, Schmitz O, et al. Liraglutide vs insulin glargine and placebo in combination with metformin and sulfonylurea therapy in Type 2 diabetes mellitus (LEAD-5 met $+\mathrm{SU}$ ): A randomised controlled trial. Diabetologia. 2009;52:2046-2055.

78. Madsbad S, Schmitz O, Ranstam J, Jakobsen G, Matthews DR Improved glycemic control with no weight increase in patients with Type 2 diabetes after once-daily treatment with the long-acting glucagon-like peptide 1 analog liraglutide (NN2211). Diabetes Care. 2004;27:1335-1342.

79. Feinglos MN, Saad MF, Pi-Sunyer FX, An B, Santiago O. Effects of liraglutide (NN2211), a long-acting GLP-1 analogue, on glycaemic control and bodyweight in subjects with Type 2 diabetes. Diabet Med. 2005;22:1016-1023.

80. Jendle J, Nauck M, Matthews D, et al. Weight loss with liraglutide, a once-daily human glucagon-like peptide-1 analogue for Type 2 diabetes treatment as monotherapy or added to metformin, is primarily as a result of a reduction in fat tissue. Diabetes Obes Metab. 2009;11:1163-1172.

81. Pratley R, Toft A, Falahati A, Plutzky J. P3-431: The once-daily human GLP-1 analog liraglutide significantly improves total cholesterol and the prevalence of metabolic syndrome in Type 2 diabetes: A meta-analysis of six clinical trials. Abstract presented at the 2009 annual meeting of the Endocrine Society. Washington DC, June 10-13, 2009.

82. Courrèges J, Vilsbøll T, Zdravkovic M, et al. Beneficial effects of once-daily liraglutide, a human glucagon-like peptide-1 analogue, on cardiovascular risk biomarkers in patients with Type 2 diabetes. Diabet Med. 2008;25:1129-1131. 
83. Astrup A, Rössner S, Van Gaal L, et al. Effects of liraglutide in the treatment of obesity: A randomised, double-blind, placebo-controlled study. Lancet. 2009;374:1606-1616.

84. Finer N, Al Hakim M, Van Gaal L, et al. The once-daily human GLP-1 analog liraglutide reduces the prevalence of prediabetes and improves systolic blood pressure in obese non-diabetic subjects: A 52-week randomized placebo-controlled trial. Obesity. 2009;17:S108.

85. Nauck MA, Ratner RE, Kapitza C, Berria R, Boldrin M, Balena R. Treatment with the human once-weekly glucagon-like peptide-1 analog taspoglutide in combination with metformin improves glycemic control and lowers body weight in patients with Type 2 diabetes inadequately controlled with metformin alone. Diabetes Care. 2009;32:1237-1243.
86. Rosenstock J, Reusch J, Bush M, Yang F, Stewart M. Potential of albiglutide, a long-acting GLP-1 receptor agonist, in Type 2 diabetes. Diabetes Care. 2009;32:1880-1886.

87. Day JW, Ottaway N, Patterson JT, et al. A new glucagon and GLP-1 co-agonist eliminates obesity in rodents. Nat Chem Biol. 2009;5: 749-757.

88. Pocai A, Carrington PE, Adams JR, et al. Glucagon-like peptide 1/ glucagon receptor dual agonism reverses obesity in mice. Diabetes. 2009;58:2258-2266.

\section{Publish your work in this journal}

Diabetes, Metabolic Syndrome and Obesity: Targets and Therapy is an international, peer-reviewed open-access journal committed to the rapid publication of the latest laboratory and clinical findings in the fields of diabetes, metabolic syndrome and obesity research Original research, review, case reports, hypothesis formation, expert opinion and commentaries are all considered for publication. The manuscript management system is completely online and includes a very quick and fair peer-review system, which is all easy to use. Visit http://www.dovepress.com/testimonials.php to read real quotes from published authors.

Submit your manuscript here: http://www.dovepress.com/diabetes-metabolic-syndrome-and-obesity-targets-and-therapy-journal 